the spermatophores attached to the plastron, and derived from them. These spermatozoids are thus in direct contact with the ova, and in the midst of the vehicle which facilitates their penetration. Fecundation, then, is accomplished in this chamber-that is to say, outside the genital organs of the female.

M. C. Robin, who has been kind enough to ascertain these facts with me, has also seen that the spermatozoids which are found in contact with the ova in the chamber which I have just described are similar to those seen in the genital organs of the males and to those in the spermatophores attached to the thorax. They are in the form of flattened cells, with 5-7 rigid immovable cilia starting from their contour, and with a barrel-shaped projection about their middle. During the first two days following the oviposition, these spermatozoids, which are very abundant around the ova and in the mucus, become spherical and pale, and remain motionless; in the following days they wither, and also become smaller, darker, and irregular. Lastly, when, after the fixation of the ova, the excess of the mucus has completely disappeared in consequence of the pressure exerted by the incessant contractions of the abdomen (which takes place in a variable period of from eight to ten days after the oviposition), those spermatophores which still remain attached to the plastron consist of small, white, coriaceous filaments, either isolated or mutually adherent; they no longer show any thing but a central cavity, in which the microscope reveals only a few more or less withered spermatozoids. The wall of these spermatophores retains its thickness, and remains, as before, composed of a concrete, striated, tenacious mucus.-Comptes Rendus, January 15, 1872, tomẹ lxxiv. pp. 201, 202.

\title{
Baptisia perfoliata, the Arrangement and Morphology of its Leaves.
}

In a paper sent by Mr. Ravenel to Prof. Gray, and read by him at the last meeting of the American Association for the Advancement of Science, the character of the torsion of the stem by which the foliage on summer shoots becomes unilateral is explained. It had been hastily supposed by the present writer that the leaves were five-ranked, and became one-ranked by a continuous torsion of the stem. Mr. Ravenel points out that the phyllotaxis of the plant in question is really of the two-ranked order, which inspection of the growing shoots makes abundantly clear, and that they become one-ranked by the alternate twisting of the successive internodes right and left; i.e. one twists to the right, the next as much to the left, the next in the opposite direction, and so on, thus bringing the leaves into a vertical position all on one side of the horizontal branch. It occurred to $\mathrm{Mr}$. Ravenel that this vertical position of the leaves was correlated with the remarkable alternate torsion of the axis-namely, that the leaves on the reclining branches were adjusting themselves so as to present their two faces as equally

ber of granulated rounded globules, isolated or united in little masses, which do not exist in the cavity of the spermatophores, where the spermatozoids alone are to be found. 
as possible to the light, as is done by those of the compass plant in a different way, and that it was therefore probable that the stomata would be found to be as numerous on the upper face of the leaf as on the lower. A microseopic examination proved the correctness of Mr. Ravenel's conjecture; the stomata are about equally numerous on the two faces. Whether the leaves take a vertical position because the stomata occupy both surfaces, or whether the stomata are so distributed because the leaves stand edgewise to the zenith, is a question. The fact is, that the two are thus correlated, and such correlation is ordinarily essential to the well-being of the plant. It may be remarked, however, that the stomata do not manifestly appear until the leaf is pretty well developed, also that this distribution of the stomata is peculiar to the species in question; at least the leaves of $B$. australis and B. leucantha, which retain their horizontal position, are provided with stomata only on their lower face. The question next arises whether $B$. perfoliata really differs in its normal phyllotaxis from its congeners. We find that it does not, that in B. australis, leucantha, and alba, and in $B$. perfoliata likewise (these being all the species at present cultivated in the Cambridge Botanic Garden), the arrangement of the leaves at the base of the main stem is of the tristichous order, but that after the first or second cycle, especially on the branches, this changes to the distichous order. The difference between $B$. perfoliata and its congeners, therefore, is not in the normal arrangement of the leaves, but in the fusion of the axis and the distribution of the stomata, adapting the foliage to its vertical position.

The form of the leaves in Baptisia perfoliata is remarkably peculiar. Most of the species have trifoliate leaves and a pair of stipules; this has to all appearance a simple and entire perfoliate leaf and no stipules. It is, however, a natural supposition that the apparently simple leaf consists either of a pair of stipules, or of such stipules and a leaflet connate into a rounded disk. This supposition Mr. Ravenel has just now had the good fortune to verify, by finding some abnormal shoots of $B$. perfoliata, one of which is in our possession. Most of its leaves are cordate-clasping rather than perfoliate, and with or without a retuse or emarginate apex, some almost two-parted so as to represent pretty obviously a pair of stipules, and one of like conformation but with an obvious terminal leaflet in the sinus! Mr. Ravenel remarks that this is a manifest step toward his own B. stipulacea; but it hardly invalidates that species, although the inflorescence and legume of the two are quite alike.-Prof. Asa Gray in Silliman's American Journal, Dec. 1871.

\section{On a new Micrometric Goniometer Eyepiece for the Microscope.} By J. P. Southworth.

After a few experiments by Dr. H. T. Porter and myself, we have succeeded in making an eyepiece micrometer and goniometer which equal in accuracy and surpass in simplicity and cheapness any we have seen; and we have used those of some of the best makers in this country. The objection to the eyepiece micrometers in use is the want of boldness in the division-lines, which makes 


\section{$2 \mathrm{BHL}$ Biodiversity Heritage Library}

1872. "Baptisia perfoliata, the arrangement and morphology of its leaves." The Annals and magazine of natural history; zoology, botany, and geology 9, 174-175. https://doi.org/10.1080/00222937208696560.

View This Item Online: https://www.biodiversitylibrary.org/item/54555

DOI: https://doi.org/10.1080/00222937208696560

Permalink: $\underline{\text { https://www.biodiversitylibrary.org/partpdf/53778 }}$

\section{Holding Institution}

Smithsonian Libraries

\section{Sponsored by}

Smithsonian

\section{Copyright \& Reuse}

Copyright Status: Public domain. The BHL considers that this work is no longer under copyright protection.

This document was created from content at the Biodiversity Heritage Library, the world's largest open access digital library for biodiversity literature and archives. Visit BHL at https://www.biodiversitylibrary.org. 